\title{
The Effect of Public Awareness on the COVID-19 Pandemic in Turkey: Analysis of Google Trends Data
}

\author{
Türkiye'de Kamuoyu Farkındaıı̆ının COVID-19 Pandemisi Üzerine Etkisi: Google Trend \\ Verileri Analizi
}

\section{(D) Keziban AVCI}

Ankara Yıldırım Beyazıt University Faculty of Health Sciences, Department of Health Management, Ankara, Turkey

\section{Abstract}

Introduction: As the risk of infection in a pandemic is determined by both the individual's behavior and the object being interacted with, understanding how information-seeking behaviors and risk perceptions is critical for public health outcomes.

Materials and Methods: This study aimed to analyze interrelated digital footprint data on the internet between January 1 and May 1, 2020 in Turkey. The first data were about search on measures to reduce the spread of Coronavirus disease-2019 (COVID-19) on Google. The second data were obtained from web research using terms related to COVID-19 such as "Coronavirus" and "Koronavirüs" on Google. In addition, this study aimed to examine whether there was a correlation between Google search volumes on measures to reduce the spread of COVID-19 and the total number of confirmed COVID-19 cases, recoveries, and deaths.

Results: Until the virus was detected in Turkey, it is observed that many COVID-19 related web searches were conducted. The apex point was seen around March 11, 2020, when the first case was announced in the country. The continuous high search volumes about COVID-19 were 28 days from March 11 to April 8, 2020, and a diminishing trend in web searches was observed after April 8. A strong positive correlation was found between the search terms "Corona" and measures to reduce the spread of the virus. On the other hand, there is a strong negative correlation between search volumes and the number of COVID-19.

Conclusions: As countries endeavor to flatten the pandemic curve and reduce deaths and long-term restrictions, understanding how individuals respond to this situation has become more important than ever for the ultimate solution to the current crisis. Therefore, authorities should further strengthen/raise national awareness of COVID-19 and keep the public informed.

Keywords: Coronavirus, measure, risk perception, public interest, Google Trends

\section{Öz}

Giriş: Bir pandemide enfeksiyon riski, hem bireyin davranışı hem de etkileşimde bulunulan nesne tarafından belirlendiğinden, bilgi arama davranışı ve risk algılarının toplumda nasıl değişebileceğini anlamak halk sağlığı sonuçları için kritik öneme sahiptir.

Gereç ve Yöntem: Bu çalışmanın amacı, Türkiye'de 1 0cak-1 Mayıs 2020 tarihleri arasında internetteki birbiriyle ilişkili dijital ayak izi verilerini analiz etmektir. İlk veriler, Koronavirüs hastalığı-2019'un (COVID-19) yayılmasını azaltmaya yönelik önlemlerin Google'da araştırılmasıyla ilgilidir. İkinci veriler, Google'da "Coronavirus", "Koronavirüs" gibi COVID-19 ile ilgili arama terimleriyle yapılan web araştırmasından elde edildi. Ayrıca, bu çalışma COVID-19"un yayılmasını azaltmaya yönelik önlemlere ilişkin Google arama hacimleri ile doğrulanan COVID-19 olgu, iyileşen ve ölen sayıları arasında bir ilişkisi olup olmadığını incelemeyi amaçlamıştır.

Bulgular: Türkiye'de virüs tespit edilinceye kadar çok sayıda COVID-19 ile ilgili web araması yapıldığı görülmüştür. Zirve noktası, ülkede ilk olgunun açıklandığı 11 Mart 2020 civarında görülmüştür. Koronavirüs hastalığı-2019 ile ilgili sürekli yüksek arama hacimleri 11 Mart 2020'den 8 Nisan 2020'ye kadar 28 gündür. 8 Nisan'dan sonra web aramalarında bir azalma trendi görülmüştür. "Corona" arama terimleri ile azaltma önlemleri arasında güçlü bir pozitif korelasyon bulunmuştur. Öte yandan, arama hacimleri ile COVID-19 olgu sayıları arasında güçü bir negatif korelasyon vardır.

Cite this article as: Avcı K. The Effect of Public Awareness on the COVID-19 Pandemic in Turkey: Analysis of Google Trends Data. Mediterr J Infect Microb Antimicrob. 2021;10:3. 


\section{Öz}

Sonuç: Ülkeler pandemi eğrisini düzleştirmeye, ölümleri ve uzun süreli kısıtlamaları azaltmaya çalışırken, bireylerin bu duruma nasıl tepki verdiklerini anlamak mevcut krizin nihai çözümü için her zamankinden daha önemli hale gelmektedir. Bu nedenle, yetkililer COVID-19 konusunda ulusal farkındalığı daha güçlendirmeli/artırmalı ve halkı bilgilendirmelidir.

Anahtar Kelimeler: Koronavirüs, önlem, risk algısı, toplum ilgisi, Google Trends

\section{Introduction}

In December 2019, a novel coronavirus was reported in Wuhan, China $^{[1]}$. The World Health Organization immediately declared it as a pandemic on March 11, 2020, due to the rapid spread of the virus to many countries in a short time ${ }^{[2]}$. The virus was named severe acute respiratory syndrome coronavirus-2 (SARS-CoV-2). By May 1, 2020, 3,489,053 confirmed cases were reported, and 241,559 people died from Coronavirus disease-2019 (COVID-19) worldwide ${ }^{[3]}$.

Causes such as the alarming spread of COVID-19, difficulty in controlling its spread and grave health consequences, and lack of effective drug and vaccine have encouraged official authorities to take measures to reduce the spread of COVID-19 such as closures of schools, mosques, churches, and even international borders $^{[4,5]}$. Measures to reduce the spread of COVID-19 have significant psychological, social, and economic impacts and have greatly affected people's daily lives.

When faced with an important situation, people wonder and search what they encounter, how they can control the spread of COVID-19, and what they can do in terms of precaution measures. In the digital age, this concern is reflected in internet searching behaviors. According to Kata, 80\% of internet users search for health information online. However, the same study also warned that the Internet facilitates the spread of misinformation and good information ${ }^{[6]}$. Despite this concern, the use of internet data is being increasingly preferred in the health area for predicting and analyzing human behaviors. Also, online search data are being widely used for predicting and monitoring disease occurrence and outbreaks ${ }^{[7]}$. The most popular tool in addressing health issues and topics with the use of internet data is Google Trends, an open online tool that provides both real-time and archived information ${ }^{[8,9]}$.

The important issue in the use of internet data is the availability of digital infrastructure and widespread access of network. Internet penetration is high in Turkey. The rate of using information technologies in institutions was 96.7\% in 2019. In the same period, the rate of internet access at home was 88.3\%. Majority of the population (75.3\%) actively use internet, and most users are between 16 and 74 years old ${ }^{[10]}$. The average daily time spent on the Internet is around $7 \mathrm{~h}^{[11]}$.

\section{The Situation of the COVID-19 Pandemic in Turkey}

The Turkish government has managed the COVID-19 pandemic according to a national pandemic plan advised by the Coronavirus Scientific Advisory Board ${ }^{[12]}$.

The first case was announced in Turkey on March 11, 2020. Before COVID-19 arrived in country, the government began taking temperature upon arrivals at international airports. Then, the government announced travel restrictions in 31 metropolitan cities. By this time, flights had been suspended between Turkey and different countries. Citizens who were returning from abroad were also put in quarantine for 14 days $^{[13-15]}$.

During the early stages of the outbreak, the government began taking steps to curtail interactions between infected and uninfected populations. The methods used include isolation of infected patient, quarantine, social distancing practices, school and mosque closure, and travel restrictions. On March 11, the government began issuing "stay at home" orders. A total curfew was imposed for people under 20 and over 65 years old or those with chronical illnesses. Using face masks in public places also became mandatory. Meanwhile, two pandemic hospitals have been constructed to manage COVID-19 cases in Istanbul, which has a higher proportion of cases and deaths ${ }^{[13-15]}$.

As of May 1, 2020, the number of cases in the country was over 129,491, of which 73,285 recovered and 3520 died. The fatality rate in Turkey (around 3.7\%) increased for several reasons such as the relatively young population of the country, a higher number of available intensive care beds, and the number of tests performed ${ }^{[12]}$.

The purpose of this study was to analyze interrelated digital footprint data on the Internet between January 1 and May 1, 2020, in Turkey. The first data were about search on measures to reduce the spread of COVID-19 on Google. The second data were obtained from web research using terms related to COVID-19 such as "Coronavirus" and "Koronavirüs" on Google. In addition, this study aimed to examine whether there was a correlation between Google search volumes on measures to reduce the spread of COVID-19 and the total number of confirmed COVID-19 cases, recoveries, and deaths. 


\section{Materials and Methods}

Research Questions

We aimed to answer the following questions in this study:

1. Is there any correlation between the total number of confirmed COVID-19 cases, recoveries, and deaths, data about search on measures to reduce the spread of infection, and data about the use of search terms related to COVID-19 on Google?

2. Is there any similarity between web search on those protective measures against the infection and the number of confirmed COVID-19 cases, death, and recoveries in Turkey?

3. Is there any similarity between web research done using terms related to COVID-19 on Google and the number of confirmed COVID-19 cases, death, and recoveries in Turkey?

4. Is there any similarity between web research done using terms related to COVID-19 on Google and web searches on those protective measures against the infection in Turkey?

5. Is there any difference among the cities of Turkey regarding web search on measures to reduce the spread of the infection?

\section{Dataset}

In this study, three datasets were used to explore the relationship between the total number of confirmed COVID-19 cases, recoveries, and deaths, measures to reduce the spread of infection, and data using search terms related to COVID-19 on Google. First, the total number of COVID-19 cases, deaths, and recoveries was obtained from the Turkish Ministry of Health and The Scientific and Technological Research Council of Turkey COVID-19 web portal ${ }^{[12,16]}$. Second, measures to reduce the spread of infection was proposed by the National Scientific Committee, selected as health protective behaviors that are easily accessible and applicable. Data about search related to these protective measures, which include frequent handwashing, social distancing, and wearing facemasks, were obtained via Google Trends. Third, data using search terms related to COVID-19 on Google were also obtained via Google Trends ${ }^{[17]}$.

Google is the most popular search engine worldwide ${ }^{[18]}$. Google Trends is an online tool that is used to retrieve data on internet user search activities, trends, and patterns of Google search ${ }^{[19,20]}$. Real-time and archived data on Google search queries are divided according to the total searches of the geography and time range it represents to compare relative popularity. These normalized data are expressed as the relative search volume (RSV). At this stage, repetitive Google searches made by the same user in a short time are not considered automatically. The retrieved data are scaled from 0 to 100, with 100 representing the maximum searching activity given relative to this. Periods with very low search volumes are identified as zero activity ${ }^{[17,21,22]}$.

\section{Search Term Selection}

The selection of the correct keywords when using web-based search data is key to obtain valid results. Google Trends is not case sensitive, but it considers accents, plural or singular forms, and spelling mistakes. Multiple terms could be entered using the plus sign $(+)$, which means "OR," to include more results. Another important aspect is the use of quotation marks for keyword with two or more words ${ }^{[21,23]}$. In this context, Google Trends data were queried in four sections.

1. COVID-19: The keywords used related to COVID-19 were "Corona" and "Korona" because of the society's high preference in the speech term. Other relevant keywords - "Coronavirus" or "Koronavirüs" or "Koronavirus" or "COVID 19" or "COVID-19" or "Pandemi (pandemic)" or "Salgın (epidemic)" or "SARS-CoV-2" or "SARS-CoV2" or "2019-nCoV" - had low search volumes, and they were deleted to avoid noisy data during the analysis period.

2. Social distancing: To indicate the search volume for social distancing measures on Google via Google Trends, the following queries were used: "stay at home (evde kal)" or "don't go out (sokağa çıkma)" or "social distancing (sosyal mesafe)" or "social isolation (sosyal izolasyon)" or "quarantine (karantina)."

3. Face mask: To indicate the search volume for face mask measures on Google via Google Trends, the following queries were used: "medical mask (tıbbi maske)" or "face mask (yüz maskesi)" or "protective mask (koruyucu maske)" or "surgical mask (cerrahi maske)" or "N95."

4. Handwashing: To indicate the search volume for handwashing on Google via Google Trends, the following queries were used: "handwashing (el yıkama)" or "hand sanitizer (el dezenfektanı)" or "hand antiseptic (el antiseptiği)" or "hand hygiene (el hijyeni)" or "antiseptic."

\section{Statistical Analysis}

SPSS version 24.0 was used for the correlation analysis between the daily search volumes of COVID-19 (with related terms), measures to reduce the spread of infection, and the number of cases, recoveries, and deaths. Since the data are not normally distributed, Spearman's rank correlation coefficients were used for the analysis. Results were considered significant if the p-value was less than 0.01 .

\section{Results}

COVID-19 Data and Search Volumes

Figure 1 compares Google Trends data of the keywords "Corona" and "Korona" and the number of confirmed cases, death, and recoveries data from January 1 to May 1, 2020. According to Figure 1, until the virus was detected in Turkey, it is observed that many COVID-19 related web searches were conducted. 
1. A small peak was seen around January 30, 2020, when the epidemic was announced in China.

2. A clear peak was seen around February 26, 2020, when the number of infections rapidly increased in close geographies such as Italy and Iran.

3. The apex point was seen around March 11, 2020, when the first case was announced in the country. This search behavior decreased toward the beginning of April, when much of the population already had knowledge about COVID-19. The continuous high search volumes about COVID-19 in Turkey were 28 days from March 11 to April 8, 2020.

\section{Measures to Reduce the Spread of COVID-19}

According to Figure 2, interest in face mask searches continued intermittently from late January to mid-April. Particularly, face mask search started to demonstrate spikes in late February.

Moreover, handwashing search trends were very similar to COVID-19 search trends (Figure 3). On the other hand, search for social distancing and face mask terms continued at high rates between mid-March and mid-April due to the rapid spread of COVID-19 and expansion of quarantine restrictions in Turkey. Overall, social distancing has the highest number of search

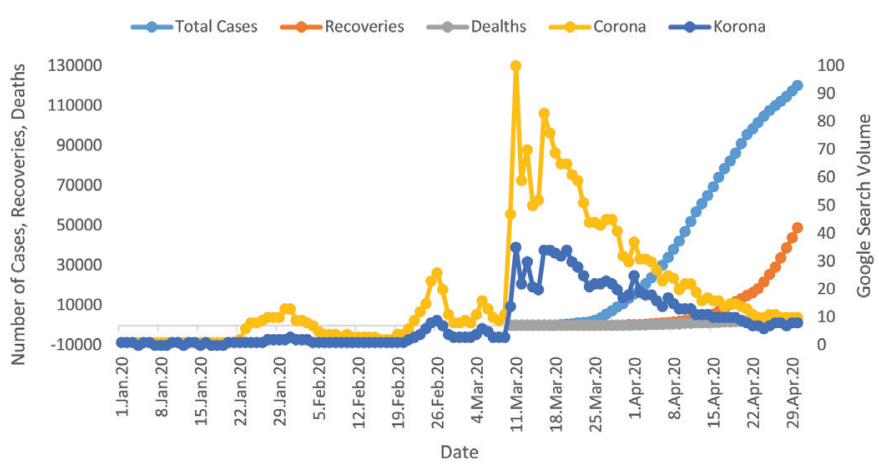

Figure 1. Coronavirus Google Trends data and the number of of Coronavirus disease-2019 cases, recoveries, and deaths among preventive measures against COVID-19. The term social distancing saw a considerable interest and attention after midMarch 2020.

\section{Regional Differences Among Measures to Reduce the Spread} of COVID-19

Figure 3 shows the distribution of search volumes for the protective measures against COVID-19 among the cities in Turkey. According to the RSV, social distancing was the most

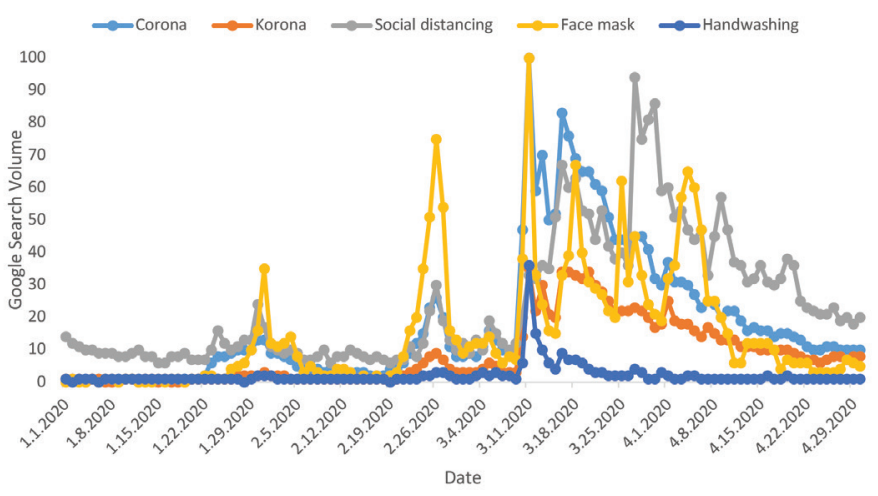

Figure 2. Comparison of Google web search trends

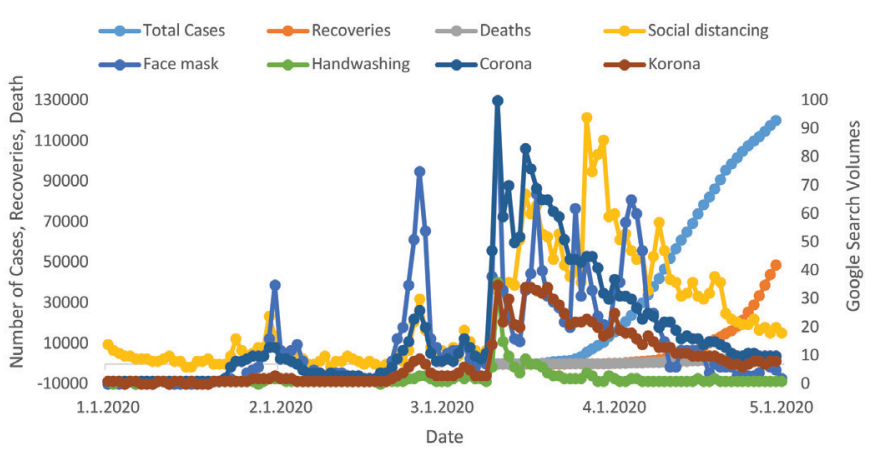

Figure 3. Comparison of Google web search trends and the number of Coronavirus disease-2019 cases, recoveries, and deaths

Table 1. Correlation matrix between relative search volume indexes and the number of Coronavirus disease-2019 cases, recoveries, and deaths

\begin{tabular}{l|l|l|l|l|l|l|l|l}
\hline & $\begin{array}{l}\text { Social } \\
\text { distancing }\end{array}$ & $\begin{array}{l}\text { Face } \\
\text { mask }\end{array}$ & $\begin{array}{l}\text { Hand } \\
\text { washing }\end{array}$ & Total cases & Recoveries & Deaths & Corona & Korona \\
\hline Social distancing & 1.000 & & & & & & & \\
\hline Face mask & $0.732^{* *}$ & 1.000 & & & & & & \\
\hline Hand washing & $0.531^{* *}$ & $0.680^{* *}$ & 1,000 & & & & & \\
\hline Total cases & $-0.599^{* *}$ & $-0.779^{* *}$ & $-0.837^{* *}$ & 1.000 & & & & \\
\hline Recoveries & $-0.643^{* *}$ & $-0.779^{* *}$ & $-0.825^{* *}$ & $0.992^{* *}$ & 1.000 & & & \\
\hline Deaths & $-0.583^{* *}$ & $-0.759^{* *}$ & $-0.838^{* *}$ & $0.999^{* *}$ & $0.991^{* *}$ & 1.000 & & \\
\hline Corona & $0.883^{* *}$ & $0.895^{* *}$ & $0.687^{* *}$ & $-0.976^{* *}$ & $-0.984^{* *}$ & $-0.976^{* *}$ & 1.000 & \\
\hline Korona & $0.900^{* *}$ & $0.844^{* *}$ & $0.632^{* *}$ & $-0.915^{* *}$ & $-0.939^{* *}$ & $-0.916^{* *}$ & $0.963^{* *}$ & 1.000 \\
\hline${ }^{* *}<<0.01$ & & & & & &
\end{tabular}


searched protective measure, and this search trend was seen in every city. The two cities in the central Anatolia region have searched face masks more than istanbul where the number of cases and deaths was the highest. Search volumes for handwashing were also higher in the two cities with a high number of cases.

It was found that search volumes between measures to reduce the spread of COVID-19 differed among cities. The search intensity was low in cities such as Ağrl, Hakkari, and Kilis where the number of cases and population was low. On the other hand, several cities have a high number of searches, although the density of patients is relatively not high (Figure 4). This situation has given rise to the thought that people who live in these cities have a high risk perception level regarding COVID-19.

\section{Correlation Matrix of RSV Index and COVID-19}

Table 1 presents Spearman's rank correlation matrix of RSV index for COVID-19 and measures to reduce the spread of infection between COVID-19 cases, recoveries, and deaths from January 1 to May 1, 2020.

Results show that the RSV for measures to reduce the spread of COVID-19 is significant and positively correlated with each other. A strong positive correlation was noted between the search terms "Corona" and "Social distancing" $(r=0.883$, $p<0.01)$, "Face mask" ( $r=0.895, p<0.01)$, and "Handwashing" $(r=0.687, p<0.01)$. The results are similar for the "korona" search term. There were significant negative correlations between the RSV for the keywords "corona" and "korona" and the number of COVID-19 cases, recoveries, and deaths. A significant negative

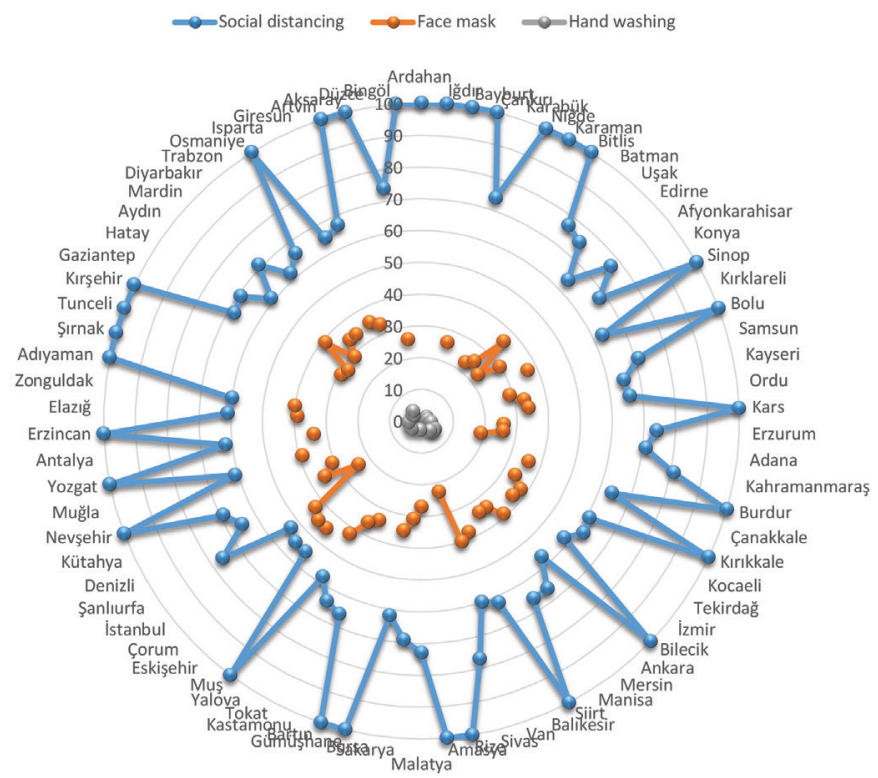

Figure 4. Comparison of Google Trends data on the protective measures to reduce the spread of Coronavirus disease-2019 by cities correlation was found between the RSV for "social distancing" and the number of recoveries $(r=-0.643, p<0.01)$. Similarly, there was a negative correlation between the RSV for "social distancing" and the number of COVID-19 cases and deaths. There were significant negative correlations between the RSV for "face mask" and "hand washing" and the number of COVID-19 cases, recoveries, and deaths.

\section{Discussion}

The study provided a glimpse of people's search activity using Google Trends data between January 1 and May 1, 2020 in Turkey. An important observation in the study is the intensity of web search activities on COVID-19 related terms and measures to reduce the spread of infection in the country. The increased internet search queries indicated that more people proactively engaged in COVID-19 and measures to reduce the spread of infection, which may have had an effect on reducing the spread of COVID-19 outbreak after nearly 4 weeks (from March 11 to April 8, 2020).

In Turkey, the first COVID-19 case was announced on March 11, 2020, and the first death was recorded on March 16, 2020. After the first case, the number of cases has rapidly increased, exceeding 100,000, and the death rate was over 3000 . Consistent with search volumes reflecting risk perceptions, there was a drastic increase in Google search for COVID-19 when the first case was reported in Turkey. It can be observed that the search terms reached a maximum level of interest during mid-March as the case numbers significantly increased in close countries such as Iran and Italy. During the COVID-19 pandemic, the experience of these countries had caused worry and anxiety among people in Turkey. According to a study by Strzelecki ${ }^{[24]}$, the worldwide search trends are significantly, positively, and strongly correlated with the trends in China, Italy, South Korea, and Iran.

The duration of public attention for COVID-19 was 28 days in Turkey. Hu et al. ${ }^{[18]}$ revealed that this duration was $27,23,22$, 13, and 11 days in the United States, United Kingdom, Australia, Canada, and New Zealand, respectively. The Center for Diseases Control and Prevention and the federal and local health departments have played an important role in increasing public attention in the United States by applying robust methods to prevent the spread of diseases and to increase public awareness associated with public health. It can be interpreted that increase in public attention in those aforementioned countries occurred immediately after the announcement of the first confirmed cases.

It is observed that web searches on "face mask" were almost similar before the first recorded COVID-19 case in Turkey and its aftermath. The significant increase in searches for "face mask" revealed the general population's worry toward 
COVID-19 and general anxiety toward sufficient face mask supply. The increased search for "face mask" might indicate the increased number of people wearing face masks, but it might also result from the short supply or increase in face mask demand in the country. According to Lin et al. ${ }^{[25]}$, "the increased Google search for 'wash hand' would simply indicate people engaged more in hand hygiene". On the other hand, our findings show that the least searched web query was "handwashing" during the research period. However, before putting on a face mask ${ }^{[26]}$ and after touching the outer mask surface ${ }^{[27]}$, it is suggested that hands should be washed with soap and water for at least $20 \mathrm{~s}$. The awareness of handwashing is still the most useful infection control measure during the COVID-19 pandemic ${ }^{[25]}$. Lin et al. ${ }^{[25]}$ found that the increased Google searches for "handwashing" correlated with a lower spread rate of COVID-19. This study highlights the importance of public awareness of handwashing to prevent the spread of COVID-19.

Another important observation in our study is that the public's interest in social distancing takes longer than other measures to reduce the spread of COVID-19. Social distancing means keeping a safe distance of around 6 feet from others, avoiding contact with people, and staying at home ${ }^{[5,28,29]}$. Since a comprehensive curfew was implemented in Turkey, it is unsurprising to see the popularity of this topic.

Results suggest that despite the increasing case numbers in the country, public interest in COVID-19 did not increase that much. There was a strong negative correlation between the Google search volumes and number of COVID-19 cases in Turkey, which means that people care enough for COVID-19.

This study suggests that interest in COVID-19 for either education or protection can have an impact on the awareness of the public and the spread of the virus. As the awareness level increases, it is expected that precautionary behaviors will be more common ${ }^{[30]}$. In other words, the behavior of an individual who is faced with a threat is an emotional response to escape from that threat. On the other hand, if the worry that is caused by the fear of getting infected is not controlled, panic may prolong the pandemic. The worry over a threat creates an environment where individuals immediately react to the stimuli ${ }^{[31]}$. In this context, circulating myths and gossips have the potential of "emotional contagion" during the pandemic.

Another factor reflecting the risk perception of COVID-19 is trust. According to the trust and confidence model, the existence of a threat that affects people's decisions about the risks and related benefits may impact the adoption of the recommended measures to reduce the spread of COVID-19. Therefore, confidence in authorities will help countries effectively manage public communication and handle crisis during the pandemic period. It is a key for authorities to provide accurate information to the public about the pandemic to prevent panic and increase awareness level[ ${ }^{[31,32]}$.

As is evident by the findings of this study, there are limitations to the use of Google Trends analysis. First, this method requires individuals to have access to the Internet and to be actively engaged in searching. This study, therefore, does not represent the total population of Turkey. Second, sociodemographic factors such as age and sex were excluded from the analysis because it was impossible to recognize the people who did the web search. Third, the selection of user input of query keywords plays a crucial role in ensuring the validity of the results. Although several keywords or keyword combinations were chosen, there is a risk that several other keywords related to COVID-19 might be dismissed.

\section{Conclusion}

There are no previous studies on the public's risk perception of COVID-19 particularly quantitative studies that try to measure risk perception through web searches of internet users. Thus, this study attempts to fill this gap on people's perception of COVID-19. As the risk of infection in a pandemic is determined by both the individual's behavior and the object being interacted with, understanding how information-seeking behaviors and risk perceptions is critical for public health outcomes.

As countries struggle to flatten the pandemic curve and lessen deaths and prolonged restrictions, understanding how individuals react to this situation becomes of more importance to the ultimate resolution of the current crisis. The limited availability of most health data, especially the large timeframe needed for data collection and analysis on disease occurrence, means researchers cannot access real-time data. However, this is extremely important for health assessment. In this context, data from several online sources are being widely used to monitor outbreaks and their occurrence ${ }^{[8,9]}$.

Results show that the population in Turkey has a high awareness level about the pandemic. On the other hand, low mortality rates reduce interest in measures to reduce the spread of COVID-19. It is stated that major coronavirus outbreaks frequently occur in waves, and the first wave may be accompanied by a misleading sense of immunity in survival. Such a case "can lead to apparently conflicting worry-behavior correlations" ${ }^{\prime[31]}$. Therefore, to reduce deaths associated with COVID-19, authorities need to make continuous public health activities to increase public awareness and inform communities within a system that provides adequate and appropriate measures for protection. In this way, it will be possible to prevent disease-related emergency demand, shorten the community's reaction time of the disease, and reduce potential losses. 
As a result, this study has shown that Google Trends could be used to monitor public interest related to the pandemic. Therefore, authorities should strengthen further the publicity of COVID-19 nationally and inform the public.

\section{Ethics}

Ethics Committee Approval: The search query trend data gathered from Google Trends were freely available information and fully anonymized.

Peer-review: Externally and internally peer-reviewed.

Financial Disclosure: The author declared that this study received no financial support.

\section{References}

1. Guo YR, Cao QD, Hong ZS, Tan YY, Chen SD, Jin HJ, Tan KS, Wang DY, Yan Y. The origin, transmission and clinical therapies on coronavirus disease 2019 (COVID-19) outbreak - an update on the status. Mil Med Res. 2020;7:1-11.

2. Lu R, Zhao X, Li J, Niu P, Yang B, Wu H, Wang W, Song H, Huang B, Zhu N, Bi Y, Ma X, Zhan F, Wang L, Hu T, Zhou H, Hu Z, Zhou W, Zhao L, Chen J, Meng Y, Wang J, Lin Y, Yuan J, Xie Z, Ma J, Liu WJ, Wang D, Xu W, Holmes EC, Gao GF, Wu G, Chen W, Shi W, Tan W. Genomic characterisation and epidemiology of 2019 novel coronavirus: implications for virus origins and receptor binding. Lancet. 2020;395:565-74.

3. WHO Coronavirus (COVID-19) Dashboard. World Health Organization (WHO) Web site. Last accessed date: 2020 May 5. Available from: https:// covid19.who.int

4. Carlos WG, Dela Cruz CS, Cao B, Pasnick S, Jamil S. Novel Wuhan (2019nCoV) Coronavirus. Am J Respir Crit Care Med. 2020;201:P7-P8.

5. Bhattacharya S, Singh S. (2020). Visible Insights of the Invisible Pandemic: A Scientometric, Altmetric and Topic Trend Analysis. arXiv:2004.10878.

6. Kata A. Anti-vaccine activists, web 2.0, and the postmodern paradigman overview of tactics and tropes used online by the anti-vaccination movement. Vaccine. 2012;30:3778-89.

7. Jun S, Yoo H S, Choi S. Ten years of research change using Google Trends: From the perspective of big data utilizations and applications. Technol Forecast Soc Change. 2018;130:69-87.

8. Chunara R, Goldstein E, Patterson-Lomba O, Brownstein JS. Estimating influenza attack rates in the United States using a participatory cohort. Sci Rep. 2015;5:9540.

9. Mavragani $A$, Ochoa $G$. The Internet and the anti-vaccine movement: Tracking the 2017 EU measles outbreak. Big Data Cogn Comput. 2018;2:118.

10. The Turkish Statistical Institute, TurkStat, Use of Information and Communication Technology (ICT) in Enterprises, Survey on Information and Communication Technology (ICT) Usage Survey in Households and by Individuals, 2019 Web site. Last accessed date: 2020 May 5. Available from: http://www.tuik.gov.tr/PreHaberBultenleri.do?id=30574

11. Deloitte Digital, TUSIAD. E-Ticaretin gelişimi, sınırların aşılması ve yeni normlar 2019 Web Site. Last accessed date: 2020 May 5. Available from: http://www.tubisad.org.tr/tr/images/pdf/dd-tusiad-eticaret-raporu-2019. pdf

12. Turkey Ministry of Health. COVID-19 Yeni Koronavirüs Hastalığı Web site. Last accessed date: 2020 May 5. Available from: https://covid19.saglik.gov. $\operatorname{tr} /$
13. The Ministry of the Internal Affairs. "Korona" Search Resulth Web Site. Last accessed date: 2020 May 5. Available from: https://www.icisleri.gov. tr/arama/ara/korona. Turkey Ministery of Health. COVID-19. Updated: April 7, 2020. Last accessed date: May 5, 2020. Available from: https://covid19. saglik.gov.tr/

14. Anadolu Agency (AA). Koronavirüs Web site. Last accessed date: 2020 May 5. Available from: https://www.aa.com.tr/tr/koronavirus

15. Campaign TR. COVID-19 Salgınına Karşı Alınan Tedbir ve Önlemler Web site. Last accessed date: 2020 May 5. Available from: https://www.campaigntr. com/covid-19-salginina-karsi-alinan-tedbir-ve-onlemler/

16. The Scientific and Technological Research Council of Turkey (TÜBITAK) Covid 19 Web Portal. Situation in Turkey Web site. Last accessed date: 2020 May 5. Available from: https://covid19.tubitak.gov.tr/turkiyede-durum

17. Google Trends. Trends help Web site. Last accessed date: 2020 May 5. Available from: https://support.google.com/trends/answer/6248105?hl=enctref_ topic $=6248052$

18. Hu D, Lou X, Xu Z, Meng N, Xie Q, Zhang M, Zou Y, Liu J, Sun G, Wang F More effective strategies are required to strengthen public awareness of COVID-19: Evidence from Google Trends. J Glob Health. 2020;10:011003.

19. Arora VS, McKee M, Stuckler D. Google Trends: opportunities and limitations in health and health policy research. Health Policy. 2019;123:338-41.

20. Effenberger M, Kronbichler A, Shin Jl, Mayer G, Tilg H, Perco P. Association of the COVID-19 pandemic with Internet Search Volumes: A Google TrendsTM Analysis. Int J Infect Dis. 2020;95:192-7.

21. Mavragani A, Ochoa G. Google Trends in Infodemiology and Infoveillance: Methodology Framework. JMIR Public Health Surveill. 2019;5:e13439.

22. Jarynowski A, Wojta-Kempa M, Belik V. Perception of emergent epidemic of COVID-2019 / SARS CoV-2 on the Polish Internet. MedRxiv. 2020;1-21.

23. Scharkow $M$, Vogelgesang J. Measuring the public agenda using search engine queries. Int J Public Opin Res. 2011;23:104-13.

24. Strzelecki A. The second worldwide wave of interest in coronavirus since the COVID-19 outbreaks in South Korea, Italy and Iran: A Google Trends study. Brain Behav Immun. 2020;88:950-1.

25. Lin YH, Liu CH, Chiu YC. Google searches for the keywords of "wash hands" predict the speed of national spread of COVID-19 outbreak among 21 countries. Brain Behav Immun. 2020;87:30-2.

26. Desai AN, Mehrotra P. Medical masks. JAMA. 2020; 323:1517-8.

27. Bae S, Kim MC, Kim JY, Cha HH, Lim JS, Jung J, Kim MJ, Oh DK, Lee MK, Choi SH, Sung M, Hong SB, Chung JW, Kim SH. Effectiveness of Surgical and Cotton Masks in Blocking SARS-CoV-2: A Controlled Comparison in 4 Patients. Ann Intern Med. 2020;173:W22-W3.

28. Sjödin H, Wilder-Smith A, Osman S, Farooq Z, Rocklöv J. Only strict quarantine measures can curb the coronavirus disease (COVID-19) outbreak in Italy, 2020. Euro Surveill. 2020;25:2000280.

29. Jackson D, Bradbury-Jones C, Baptiste D, Gelling L, Morin K, Neville S, Smith GD. Life in the pandemic: Some reflections on nursing in the context of COVID-19. J Clin Nurs. 2020;29:2041-3.

30. Khosravi M. Perceived risk of COVID-19 pandemic: The role of public worry and trust. Electron J Gen Med. 2020;17:1-2.

31. Goodwin $R$, Haque $S$, Neto $F$, Myers LB. Initial psychological responses to Influenza A, H1N1 ("Swine flu"). BMC Infect Dis. 2009;9:166.

32. Siegrist M, Zingg A. The role of public trust during pandemics. Eur Psychol. 2014;19:23-32. 